\title{
The War Of Words Sinhalese And Tamils In Canada
}

\author{
by Howard Adelman
}

\begin{abstract}
"Caught between Tamil terrorism and army repressive measures, the north has been economically devastated. The battle is no longer between a handful of terrorists attacking police posts and engaging in shootouts with army patrols. The civil war definition applies because actions of the armed forces, the inaction of the Sinhalese political leaders and the impotence of the older Tamil ones, have led the bulk of the northern Tamils to emphathize with and even support the Eelam terrorists."
\end{abstract}

The Toronto Star, January 22, 1985

In conflict situations around the world, cross words can lead to wars. In Canada, those wars produce heated words from expatriate communities. Fortunately, if one listens carefully, the fiery rhetoric provides a source of light as well as bilious smoke.

- An avalanche of calls flooded my home and office in response to my articles on Sri Lanka that appeared in the Saturday and Sunday Star three days after my return from two months abroad. Of the 159 calls, most were favourable, although only three of these were Sinhalese. One was a Moor. All the other favourable calls began with, "I am a Sri Lankan Tamil..." Sometimes the congratulations for bringing the information into the open are followed by stories of the suffering of their relatives and family. These stories corroborate and add to the picture I witnessed and heard in Sri Lanka. However, I found the calls and the visit of a delegation of five Sinhalese, who were critical of my pieces, much more revealing.

Only one clear error in the articles was pointed out. (I had found two others, but no one seemed to notice them). Though a side issue to the major thrust of the articles depicting the situation in the north, the error clearly touched a highly sensitive nerve - the language policy of the government and the language rights of Tamils. The erroneous reference was to the evident lack of Tamil support typewriters in government offices. This gave a misleading impression about the extent of the use of the Tamil language on coins, stamps, government documents and in education in Sri Lanka.

The critical callers, all Sinhalese, who frequently began with opening hyperbolic assertions, "There is not one word of truth ...", "They are totally biased ...", "Everything is wrong ...", were with one exception exceedingly polite, quite reasonable and unfanatical in discussion after the opening. Exaggerations were set aside. Only one Sinhalese female caller took an extreme position in suggesting that all Tamils be killed or expelled from Sri Lanka. Like the Sinhalese in Sri Lanka, the callers defended equal rights for Tamils, but were very opposed to granting Tamils collective rights which entailed any degree of political autonomy or self-government. This would lead to separation, then the influx by more Tamils from India and eventually the elimination of the Sinhalese community.

Given this underlying, but powerful and, I believe, authentic fear of possible loss of their Sinhalese identity - a fear which exists in a much clearer and pristine way in the Toronto community than anything I found from my interviews in Sri Lanka - these Sinhalese had a different perspective on a number of the issues discussed in my articles: current educational policy; the past labour history on plantations; the position of Tamils in Sri Lanka society; the credibility of witnesses I had interviewed in the north; and the assessment of responsibility for the current crisis.

I had reported that the Tamils occu- pied 25 percent of the positions in the professional faculties though constituting only 12.5 percent of the population. The Tamils felt discriminated against and their opportunities significantly reduced from their previous, much higher domination, of the professions because of the affirmative action programs which benefited the Sinhalese majority. Though a few thought the Tamil percentage of the university professional faculties was even higher than the average of government statistics I had used, the Sinhalese pointed out that the affirmative action program was aimed at all disadvantaged groups, though they admitted the overwhelming number of beneficiaries were Sinhalese.

What bothered them most was that I had not provided an explanation for the affirmative action programs. Tamils used to dominate the professions much more than they do now. According to my visitors, the Tamils had gained this advantage because Tamil markers gave higher marks to Tamil students. I did not engage in a debate on how this could be possible in mathematics exams or, even if it were true, why a new marking system would not be a solution to the problem rather than affirmative action. For what came out in the discussion is that the Sinhalese were hurt by any implication (even if unintended) that they were intellectually inferior, or more accurately, could not achieve the same level of excellence as Tamils.

This sense of ethnic or community pride emerged also in my historical 
reference to the past economic disadvantages of the Sinhalese and, in particular, the reference that Sinhalese laboured for British plantation owners. This, of course, is not inconsistent with the fact that Tamils from India had been brought to work on plantations because there were not enough Sinhalese willing to do such work. But the Sinhalese were hurt by this historical description, as if it implied that they were in any way inferior to Tamils.

Essentially, as the Sinhalese saw it, they were an easy-going, compliant, unassertive group, and Tamils took advantage of this situation to advance themselves at the expense of the Sinhalese. Since independence, the Sinhalese have bent over backwards to grant concessions to the Tamils and to ensure they were treated equally, but the demands and actions have only grown more extreme. Tamils continue to occupy high positions (one of the sections cut in the articles because of lack of space referred to the Chief Justice and Chief of Police who were both Tamils) and had every right to do so, but no more concessions should be given to the Tamil political demands. My giving credence to the Tamils I interviewed only helped the separatists and the terrorists.

One Sinhalese, who was a Catholic rather than a Buddhist, told me that any priest who talked about politics was a separatist supporter and was not to be trusted. The Catholic priest who was alleged to have been killed by the army was a supporter of the terrorists hiding guns in the church, he claimed. Anyway, he was not killed; he had escaped and was hiding in India.

I explained that credibility comes in part by putting together a number of factors: direct observation, the character of reports from a cross section of individuals chosen at random, the verification of the accounts by normally respected individuals, (an academic Jesuit, a respected Tamil lawyer in Jaffna openly opposed to separation), and a double check of my impressions with foreign political experts resident in Colombo. I had deliberately avoided seeing government leaders or leaders of the politi- cal parties or terrorist movements.

The terrorists attacked and destroyed a police station, killing 80 soldiers and police in one action, torched the magistrates building the week before I arrived, and blew up bridges and causeways cutting off Point Pedro the day before I arrived in Jaffna. The road on which I had driven had been blown up and refilled in five different places. My visitors felt I had insufficiently stressed the terrorist actions.

It is true I had commented on what I believed to be imprudent government attitudes towards compromise and indiscriminate army behaviour in the legitimate response to terrorist activity. The Tamil community in the north had been drastically affected pushing more and more towards separatism and even support for terrorist methods. The Sinhalese in Toronto felt that the responsibility must be placed on the terrorists. Though totally opposed to terrorism, I strongly suggested that when a government acts to deprive separatist parliamentarians of their seats, the action feeds the extremists who see no hope through debate and dialogue. Indiscriminate army actions in which the innocent are victims reinforce the alienation.

While a few were willing to concede parliamentary advocacy of autonomy was alright in principle, in the context of Sri Lanka a delegation of Sinhalese visitors believed it could not be allowed in practice. "Over my last drop of blood," an older gentleman asserted, "will Sri Lanka be divided." The point of my articles was that it already is divided - by fear, by terror, by alienation between and among communities - though not by law. And the cost in Tamil and Sinhalese blood has been very high and likely to grow much higher.

In the process there have been indiscriminate government killing of innocents to combat terrorism and a lack of sensitivity at the very least and possibly complicity in Tamil suffering by the Sri Lankan government. But whatever the faults and shortcomings of the army and the government, they are not Nazis. And what is occuring is not a holocaut The Tamils are not being taken forced marches to kill them as hap pened to the Amenians. Nor are the being shoved into ovens. There is $\mathbf{m o}$ suggestion that I can detect that th Sri Lankan government is out deprive Tamils of all their position. in universities, of all their assets and even of their lives. Tamils who wo such terms may satisfy their anger but the language does little to clanify and highlight the real problem.

\section{PROJECT PEACE}

A group of Canadians and Sri Lankans concerned about the recent ethnic problems in Sri Lanka have formed a committee, "Project Peace for a united Sri Lanka", which has charged itself with the following objectives:

1. To work towards a peaceful and united multi-ethnic Sri Lanak, by collaborating with Sri Lankans in Canada of all ethnic origins and religious persuasions.

2. To strive towards upholding and perpetuating the participatory democratic process in the island nation.

3 . To present a fair and unbiased picture of Sri Lanka, supported by empirical data, of the relations between the ethnic groups in Sri Lanka to Canadians.

4. To provide the Canadian public with historical and contemporary data on Sri Lanka, especially as they relate to situations such as the recent ethnic problems.

5 . To research into the causes of contemporary problems faced by Sri Lanka from a Sri Lankan-Canadian perspective, and to make recommendations to policy makers in Sri Lanka for workable solutions.

6. To ensure that policy makers deciding on development assistance to Sri Lanka are given an accurate picture of reasons for and consequences of Canadian aid.

We, as a group, wish to stress the ideals of moderation, accommodation, understanding, goodwill, and cooperation in the achievement of our objectives. 